\title{
Semen Analysis and Sperm Function Assays: What Do They Mean?
}

Mark Sigman, M.D., ${ }^{1}$ and Armand Zini, M.D. ${ }^{2}$

In the above mentioned article in Seminars in Reproductive Medicine, Volume 27, Number 2, 2009, pages 115-123, the authorship line is incorrect. The correct author list should read:

Mark Sigman, M.D., ${ }^{1}$ Abdulaziz Baazeem, M.D., ${ }^{2}$ and Armand Zini, M.D. ${ }^{3}$

${ }^{1}$ Brown University, Providence, Rhode Island; ${ }^{2}$ Fellow in Male Reproductive Medicine (Division of Urology), McGill University, Montreal, Quebec, Canada; ${ }^{3}$ McGill University, St. Mary's Hospital, Montreal, Canada.

Address for correspondence and reprint requests: Mark Sigman, M.D., Associate Professor Surgery (Urology), Brown University, Suite 174, 2 Dudley Street, Providence, RI 02905 (e-mail: MSigman@
Lifespan.org).

Estrogens and the Brain; Guest Editor Evan R. Simpson, Ph.D., F.A.A.

Semin Reprod Med 2009;27:294-294. Copyright (C) 2009 by Thieme Medical Publishers, Inc., 333 Seventh Avenue, New York, NY 10001, USA. Tel: +1(212) 584-4662.

DOI 10.1055/s-0029-1220864. ISSN 1526-8004. 